\title{
Histopathology of UV-B irradiated brown trout Salmo trutta skin
}

\author{
Carlos Noceda, Santiago González Sierra, Juan Luis Martínez* \\ Departamento de Biologia de Organismos y Sistemas, Universidad de Oviedo, c/Catedrático Rodrigo Uria s/n, \\ E-33071 Oviedo, Spain
}

\begin{abstract}
Specimens of brown trout Salmo trutta L. were experimentally irradiated with cumulative

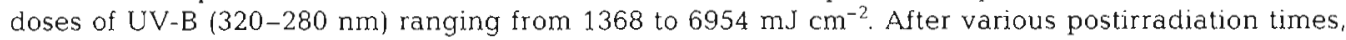
skin samples of the dorsal region of the head were processed for microscopical observations. In the irradiated epidermis, 2 types of histological effects were observed. Some effects were direct, immediate, and related to the loss of cell layers, either by increased sloughing of the surface cells or by massive detachment of the outer and middle layers. As a consequence, mucous cells disappeared from the irradiated epidermis. The restoration of normal epidermis occurred by rapid processes of cell proliferation and tissue closure resembling those of wound healing. Other effects of the UV-B radiation were not immediate and involved the production of so-called 'sunburn cells', characterized by fragmentation of the nuclear material into dense granules. No qualitative differentiation into types $A$ and $B$ sunburn cells could be made. The interpretation of these sunburn cells as being apoptotic cells is discussed.
\end{abstract}

KEY WORDS: UV-B radiation - Ozone depletion Sunburn - Histopathology - Epidermis - Salmonid

\section{INTRODUCTION}

The progressive depletion of the ozone layer in recent years has considerably increased interest in its biological consequences. Some of the most important are those caused by ultraviolet radiation, especially the $\mathrm{B}$ bandwidth (320-280 nm) which is the most biologically injurious component of sunlight (Calkins \& Thordardottir 1980). The effects of UV-B upon the skin of freshwater fishes are particularly interesting for the following reasons. Fish epidermis is a naked, nonkeratinized epithelium with no external protection against irradiation. Fish skin has photoprotective products (Fabacher \& Little 1995), but in healthy fish the pigment granules are located immediately below the basement membrane (Roberts 1975), so the epidermis is more sensitive in fish than in mammals, where there are epidermal melanosomes. Furthermore, fish epidermis plays an important role in immunological defence, both molecular and cellular, specific and nonspecific (Ellis 1981, Peleteiro \& Richards 1988), but very little it

\footnotetext{
- Addressee for correspondence.

E-mail: juanlm@sci.cpd.uniovi.es
}

is known about the responses of these mechanisms to radiation and how they are affected by it. Thirdly, UV$B$ has high levels of penetration in optically clear waters, i.e. those with low concentrations of organic or particulate matter. Under these conditions, UV-B radiation is not significantly decreased in the upper water layer (Calkins 1975, Smith \& Baker 1979). Therefore, a major incidence of irradiation damage in freshwater fish, especially in aquaculture conditions, could be expected. Research on the effects of experimental UV$B$ irradiation on fish skin has been carried out in juvenile salmonids (Bell \& Hoar 1950, Dunbar 1959, Bullock \& Roberts 1981), larvae of anchovy and mackerel (Hunter et al. 1979, 1981), platyfish-swordtail hybrids (Setlow et al. 1989) and flounders (Matsumoto \& Seikai 1992). Specifically, sunburn lesions were studied under natural conditions (Bullock et al. 1983, Bullock \& Coutts 1985, Berghahn et al. 1993) and in relation to diet (DeLong et al. 1958, Allison 1960, Bullock 1979, Bullock \& Roberts 1979), pathological conditions such as ectoparasite infestations (Bullock 1985), and wound repair (Bullock \& Roberts 1992). Excellent reviews on the pathological effects of ultraviolet irradiation on fish skin were written by Roberts \& Bullock (1981) and Bul- 
lock (1982, 1988). However, all the histopathological studies were carried out with light microscopy (LM); only Bullock (1988) added a description of scanning electron microscopy (SEM) observations of surface lesions in plaice. For this reason, we undertook the study of the effects of UV-B in brown trout epidermis with both LM and transmission electron microscopy (TEM). In this paper we present the results obtained with LM from epoxy resin embedded skin sections.

\section{MATERIALS AND METHODS}

Specimens of 2 yr old brown trout Salmo trutta L. were selected from a hatchery at Infiesto (Asturias, Spain) and kept in 2001 tanks at $10 \pm 2^{\circ} \mathrm{C}$. During irradiation exposure, movements of fishes were limited by a metallic cage, $10 \mathrm{~cm}$ deep, placed just under the water surface. The UV-B source was a bank of 6 Philips TL 20W/12 fluorescent tubes adequately aged to stabilize the emission. The tubes were installed $10 \mathrm{~cm}$ above the water surface. The spectral emission had a peak at $310 \mathrm{~nm}$. Radiation values were measured with a Delta-T MV2 microvolt integrator using a Macam SD 105B cosine-corrected underwater detector. The spectral response showed a bandwidth of $26 \pm 1 \mathrm{~nm}$ and a peak wavelength centred upon $313 \pm 2 \mathrm{~nm}$. Radiant intensity (RI) measured in the centre of the cage was $0.38 \mathrm{~mW} \mathrm{~cm}^{-2}$. Exposures ranged from 60 to $305 \mathrm{~min}$. This gave a series of cumulative doses (CD) ranging from 1368 to $6954 \mathrm{~mJ} \mathrm{~cm}^{-2}$. Daylight was not suppressed. In each treatment, 4 specimens were irradiated and 1 was untreated as a control. Skin samples were excised at postirradiation times (PIT) between 0 and $235 \mathrm{~h}$ (Table 1).

Fish were anaesthetised in aqueous MS 222 (tricaine methane sulphonate) at a concentration of 1:15000 $(\mathrm{w} / \mathrm{v})$. Pieces of scaleless skin (approximately $1 \mathrm{~mm}$ square) were taken from the dorsal region of the head and immediately fixed in $2 \%$ glutaraldehyde buffered to $\mathrm{pH} 7.2$ with $0.025 \mathrm{M}$ PIPES (piperazine-N,N'-bis[2ethanesulfonic acid]) (Hayat 1986) at room temperature for $6 \mathrm{~h}$. A concentration of $0.02 \%(\mathrm{w} / \mathrm{v}) \mathrm{CaCl}_{2}$ was added to the solution. Tissue blocks were postfixed for $2 \mathrm{~h}$ in $1 \%$ osmium tetroxide in the same buffer, also used for washing, and then left overnight at room temperature in $2 \%$ uranyl acetate buffered in the same way. Dehydration in a graded series of acetone was followed by embedding in epoxy resin (Araldite; Durcupan ACM) using propylene oxide as an intermediate solvent.

Semithin cross sections $(1 \mu \mathrm{m})$ of resin embedded skin tissue were obtained with an LKB Ultratome IV and stained with basic fuchsin-methylene blue according to the method described by Spurlock et al. (1966) or Hayat (1986).
Table 1 Treatments ( $\mathrm{T}$ ) with their respective cumulative doses (CD), irradiation times (IT) and postirradiation times (PIT)

\begin{tabular}{|rccc|}
\hline$T$ & $\begin{array}{c}C D \\
\left(\mathrm{~mJ} \mathrm{~cm}^{-2}\right)\end{array}$ & $\begin{array}{c}\text { IT } \\
(\mathrm{min})\end{array}$ & $\begin{array}{c}\text { PIT } \\
(\mathrm{h})\end{array}$ \\
\hline 1 & 1368 & 60 & 24 \\
2 & & & 148 \\
3 & & & 193 \\
4 & & 75 & 235 \\
5 & 1710 & & 0 \\
6 & & 120 & 4 \\
7 & & & 6 \\
8 & 2736 & 160 & 24 \\
9 & & & 144 \\
10 & 3648 & 180 & 0 \\
11 & & & 4 \\
12 & 4104 & & 24 \\
13 & & & 72 \\
14 & & 210 & 87 \\
15 & & 305 & 1.5 \\
16 & 4788 & & 0.25 \\
17 & 6954 & & 0.75 \\
18 & & & 2 \\
19 & & & \\
20 & & & \\
& & & \\
\hline
\end{tabular}

\section{RESULTS}

The alteration of the outer layers of the epidermis was an early and prominent effect observed in the irradiated skin of the brown trout. In healthy skin, the process of sloughing involves only the surface layer of flattened cells (Fig. 1). However, in the irradiated skin, an overall reduced affinity for dyes was seen in a wider zone including 3 to 4 upper cell layers, indicating that these layers were also affected by the irradiation (Fig. 2). Increased sloughing was detected in all the samples taken immediately after irradiation ( $0 \mathrm{~h}$ PIT) including samples irradiated for as few as $75 \mathrm{~min}$ Occasionally, increased sloughing and consequent loss of cellular adherence also were revealed by the presence of acantholytic spaces in the upper layers of the epidermis. In addition to the sloughing layers, a second zone of altered cells was visible in the middle epidermis. Below this area, large intercellular spaces forming a cleavage layer appeared immediately after irradiation at high doses (4788 $\mathrm{mJ} \mathrm{cm}^{-2}$ upwards) (Fig. 3). The irradiated epidermis showed a higher number of lymphocytes within the intercellular spaces of the cleavage layer. Sloughing of upper cells and cleavage in the middle zone produced a decrease of the thickness of the epidermis, which was frequently reduced to a few layers (Fig. 4). Occasionally, only the basal layer remained, and the basement membrane became exposed in certain areas. Scattered necrotic cells could be also seen in the irradiated epidermis. 
Fig. 1. Salmo trutta. Normal epidermis of healthy brown trout. E: epidermis; D: dermis; BM: basement membrane; FC: filamentcontaining cell; $\mathrm{MC}$ : mucous cell. Stain: basic fuchsin-methylene blue (Spurlock et al.). Scale bar = $10 \mu \mathrm{m}$

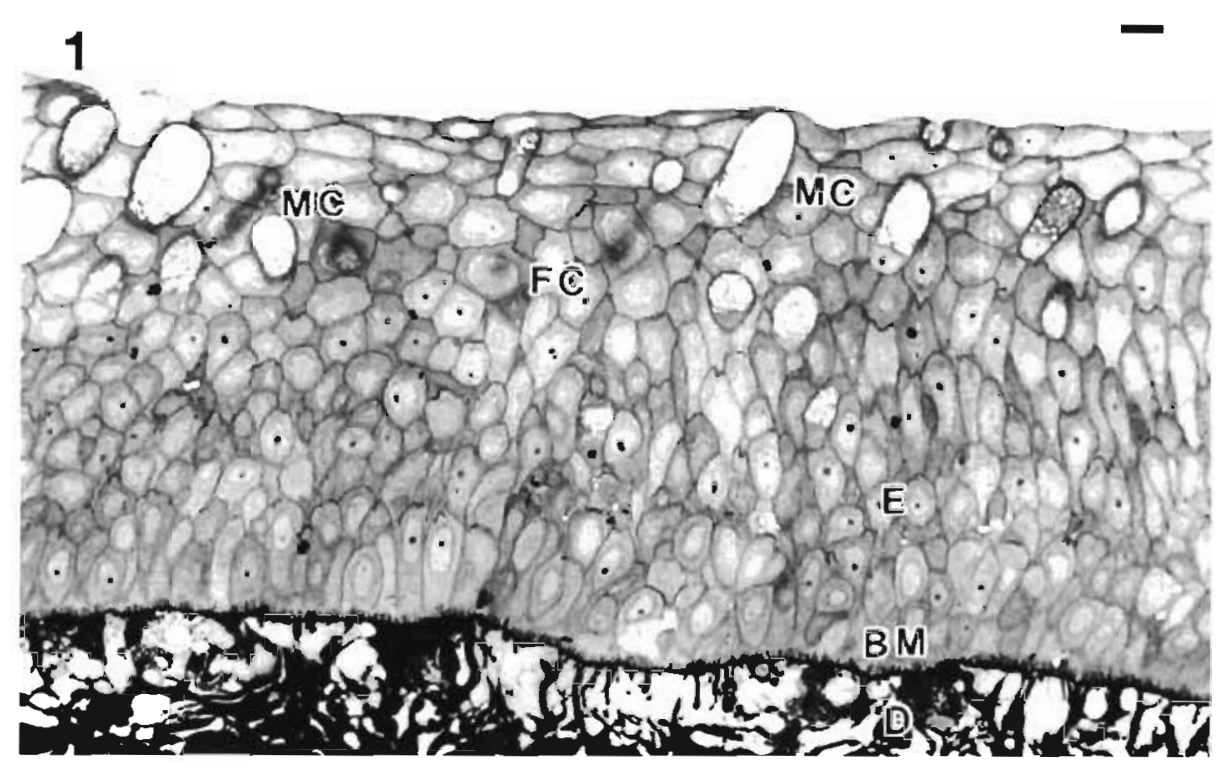

In addition to these tissue alterations, changes at the cellular level also could be seen in the filamentcontaining cells remaining after $4 \mathrm{~h}$ PIT. They showed more morphological variability than those in the healthy tissue, resulting in a loss of normal tissue architecture (Fig. 2). The nuclei of filament-containing cells also showed a major irregularity, with indented profiles. Large digestive vacuoles appeared in the cytoplasm (Fig. 4).

No qualitative differences in the effects were observed at the doses used, but a direct relation was apparent between $C D$ and quantitative intensity of the effect. For example, the loss of cell layers was greatest at the highest CD. At the lowest doses (up to $2736 \mathrm{~mJ}$ $\mathrm{cm}^{-2}$ ), the decrease of the cell layers was only due to sloughing. However, at the highest doses $(4788 \mathrm{~mJ}$ $\mathrm{cm}^{-2}$ upwards) the appearance of an epidermal cleavage caused the loss of the middle layers as a whole. Heavy sloughing and an early cleavage surface can be simultaneously seen in the epidermis shown in Fig. 2, corresponding to a medium dose $\left(3648 \mathrm{~mJ} \mathrm{~cm}^{-2}\right)$. At all irradiation doses, after $24 \mathrm{~h}$ PIT, the lack of mucous cells was evident as a consequence of the disappearance of the epithelial layers where they are located.

In all the samples taken at or after $24 \mathrm{~h}$ PIT, loss of cell layers had stopped and the process of epidermal regeneration had begun. The outermost layer of cells, regardless of the layer of origin, became flattened and joined to form a continuous epidermal surface (Fig. 5). At the same time, the cells began to recover their typical morphology according to the layer where they were located (Fig. 6). Tissue sealing and morphological restoration were more or less prominent depending on the degree of surface irregularity caused by erosion.
An increase of cellular proliferation was revealed by the presence of abundant mitotic figures (Figs. $5 \& 6$ ). This process leads to the recovery of the number of cell layers.

From $87 \mathrm{~h}$ PIT, sunburn cells appeared in the regenerating epidermis (Fig. 7). They were only observed in the upper zone of the tissue, and only if enough cell layers ( 3 or 4 at least) were preserved. Sunburn cells showed their nuclear material characteristically packed in dense granules. The only difference observed among sunburn cells was the number and size of the dense granules.

The complete recovery of normal epidermal structure required more than $10 \mathrm{~d}$ under the conditions of this experiment, because, even after this time, the samples with highest PIT still showed abundant mitotic figures and scarce mucous cells.

\section{DISCUSSION}

Some effects observed in the irradiated brown trout skin, including the increased sloughing in the epidermis or variations in mucification, are nonspecific responses that can be also seen in other pathological conditions, such as ectoparasite infestations or saprolegniasis (Robertson et al. 1981, Martinez et al. 1987). In the present work, the increased sloughing was seen immediately after the irradiation ( $0 \mathrm{~h}$ PIT), and the loss of mucous cells was complete within $24 \mathrm{~h}$. In the previous work of Bullock (1988), in salmonids these responses appeared significantly delayed and samples even showed a substantial increase in mucous cell numbers during the initial stages. Such differences 


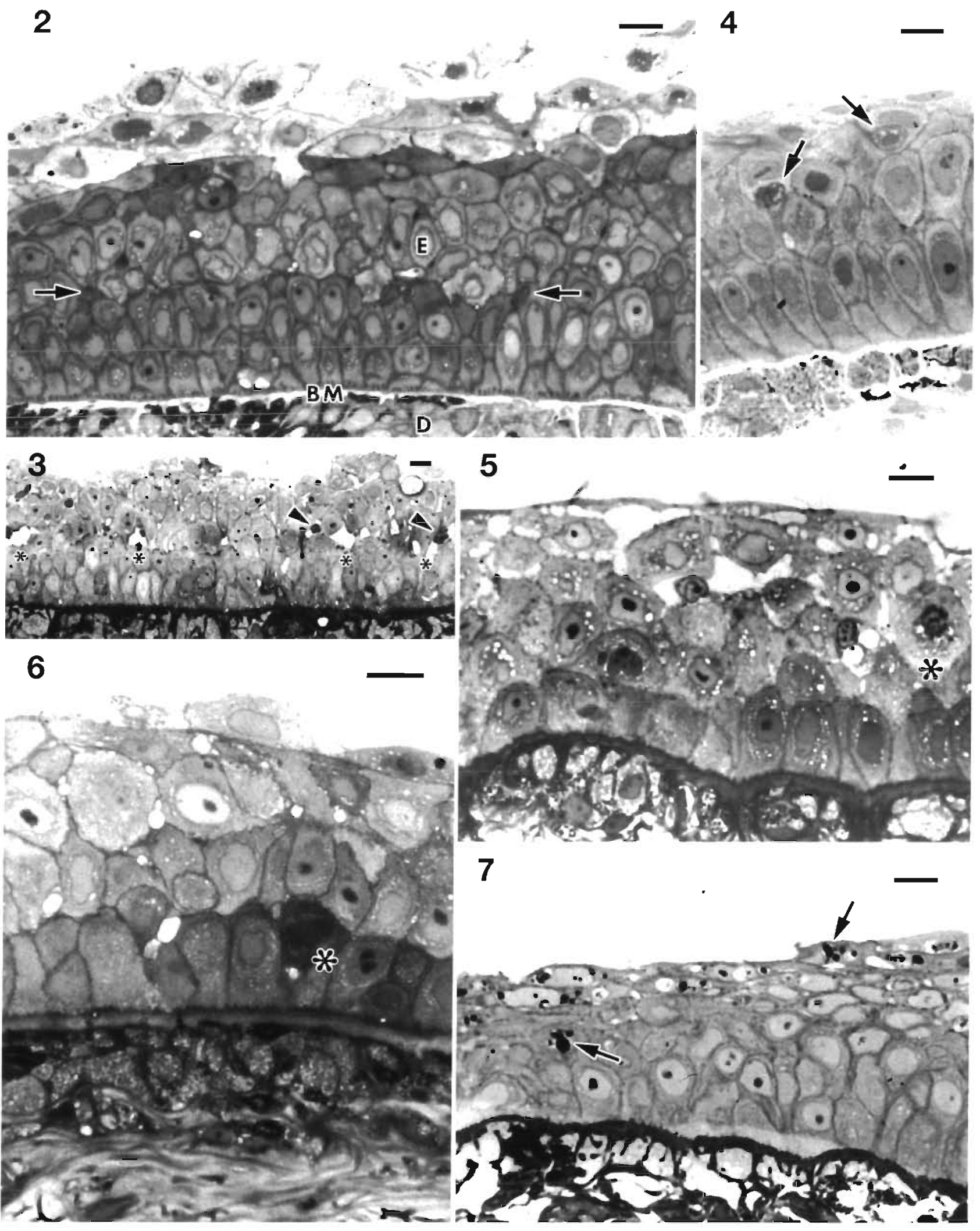


Figs. 2 to 7. Epidermis of irradiated Salmo trutta. All scale bars $=10 \mu \mathrm{m}$. Fig. 2. Irradiated epidermis showing an increased sloughing involving several upper cell layers. Between the basal and the middle zones another early alteration surface can be also seen (at level of arrows). E: epidermis; D: dermis; BM: basement membrane. Treatment T11 (see Table 1). Stain: basic fuchsin-methylene blue (Hayat). Fig. 3. Irradiated epidermis with upper cell layers lost by sloughing. Intercellular spaces forming a cleavage surface appear between the basal and middle layers (asterisks). Usually, lymphocytes (arrowheads) can be seen in the cleavage surface. T16. Stain: basic fuchsin-methylene blue (Spurlock et al.). Fig 4. Irradiated epidermis with a significant decrease in the number of cell layers as a consequence of the surface alterations. Some cells show large digestive vacuoles (arrows). T12. Stain: basic fuchsin-methylene blue (Hayat). Fig. 5. Epidermis regenerating. The restoration of the tissue integrity involved intensive mitotic proliferation (asterisk) and rapid sealing of the surface. T4. Stain: basic fuchsin-methylene blue (Spurlock et al.). Fig. 6. Epidermis regenerating. Mitotic proliferation (asterisk); few cell layers and some intercellular spaces are still visible, but the tissue surface already shows the features of normal epidermis. T3. Stain: basic fuchsin-methylene blue (Spurlock et al.). Fig. 7. Epidermis with abundant sunburn cells. Note the fragmentation of their nuclear material into several dense granules (arrows). T14. Stain: basic fuchsin-methylene blue (Spurlock et al.)

could be the results of our considerably higher RI $\left(0.38 \mathrm{~mW} \mathrm{~cm}{ }^{-2}\right)$ in comparison to that applied by Bullock $\left(0.06 \mathrm{~mW} \mathrm{~cm}^{-2}\right)$, although the cumulative doses are similar. The higher RI seemed to provoke greater epidermal erosion. For the same reason, the disappearance of mucous cells, which was observed at an earlier stage in this work than in that of Bullock, might simply be due to the loss of epithelial layers where they are located. We did not observe the AGCs (acidophilic granule cells) for which migration, swelling and rupture were reported as the initial response to UV-B in plaice epidermis (Roberts \& Bullock 1981).

The irradiation resulted in an acceleration of all the processes of epidermal regeneration in an effort to replace, by means of intensive mitotic proliferation, the cells directly damaged. Nevertheless, the loss of epidermal integrity facilitates entry of pathogens and causes osmotic disturbances (Pickering \& Richards 1980). For these reasons, processes also occur to restore tissue closure quickly. The cells of the basal or suprabasal zones of the epidermis, located on the surface after epidermal erosion, showed high plasticity and started tissue reconstruction by becoming flattened, joining, and making a continuous layer. This resembled the events that take place during wound healing (Mittal \& Munshi 1974, Phromsuthirak 1977, Iger \& Abraham 1990). Bullock \& Roberts (1992) reported that UV-B irradiation does not inhibit the epithelial cell migration that occurs in wound repair. The presence of phagocytic vacuoles in fish epithelial cells was described in the cited studies on wound healing, but the conversion of neighbouring normal cells into phagocytic cells has also been documented in a number of different situations (Peleteiro \& Richards 1990, Sanders \& Wride 1995).

The cleavage plane that appeared in the epidermal middle zone seems to be a system for en bloc elimination of damaged cells, complementing the sloughing of surface layers when the skin is irradiated at high doses. The occurrence of the cleavage plane and the increase of lymphocytes at this level suggest a reinforcement in defence mechanisms for preservation of the remaining cell layers, thus facilitating tissue restoration.

Sunburn cells first appeared $87 \mathrm{~h}$ after irradiation. These cells may represent an indirect and delayed effect shown by epithelial cells injured by the irradiation and later developing the features of sunburn cells. Bullock (1988) supported the occurrence in fish of A and B sunburn cell types. Type A has been described as possessing a piknotic nucleus with a perinuclear halo, resembling that of sunburn cells reported in mammals. Type $B$ was described as consisting of one or more spherical pyknotic nuclei. However, we observed no qualitative differences in the sunburn cells; the only difference was the number of nuclear granules showed in the section. Wyllie et al. (1980) believed that sunburn cells are apoptotic cells. Therefore, nuclear granules may result from nuclear fragmentation produced by the activation of endonucleases (Sanders \& Wride 1995). Acantholysis involved in sloughing could favour the appearance of sunburn cells, because disruption of the interactions between normal epithelial cells and the extracellular matrix induces apoptosis (Frisch \& Francis 1994), but certain other pathological conditions that involve acantholysis do not produce these cellular features. However, it is known that moderate doses of various types of radiation can cause increased apoptosis, rather than necrosis, particularly in cell populations that normally proliferate continuously (Wyllie et al. 1980), such as the fish epidermis. This could explain why sunburn cells appear before epidermal sloughing when RI is significantly lower (Bullock 1988). Nevertheless, we have not found any evidence that affirms that sunburn cells were apoptotic. Further research is necessary to investigate UVB-induced tissue changes and the structure of sunburn cells to determine whether they are apoptotic cells. A study by electron microscopy of the same irradiated samples is now under way. 
Acknowledgements. We thank Oliva Buelga and José Molina for technical assistance. This study was supported by an FICYT grant (PB - REC97-01) from the II Plan Regional de Investigación del Principado de Asturias.

\section{LITERATURE CITED}

Allison LN (1960) 'Sunburning' fingerling lake trout with ultra-violet light and the effect of a niacin-fortified diet. Prog Fish-Cult 22:114-116

Bell GM, Hoar WS (1950) Some effects of ultraviolet radiation on sockeye salmon eggs and alevins. Can J Res 28:35-43

Berghahn R, Bullock AM, Karakiri M (1993) Effects of solar radiation on the population dynamics of juvenile flatfish in the shallows of the Wadden Sea. J Fish Biol 42:329-345

Bullock AM (1979) Skin photosensitisation by phenothiazine in cultured ldinbow trout Salmo gairdneri (Richardson). Vet Rec 104:55

Bullock AM (1982) The pathological effects of ultraviolet radiation on the epidermis of teleost fish with reference to the solar radiation effect in higher animals. Proc $\mathrm{R}$ Soc Edinb 81B:199-210

Bullock AM (1985) The effect of ultraviolet-B radiation upon the skin of the plaice, Pleuronectes platessa L., infested with the bodonid ectoparasite Ichthyobodo necator (Henneguy, 1883). J Fish Dis 8:547-550

Bullock AM (1988) Solar ultraviolet radiation: a potential environmental hazard in the cultivation of farmed finfish In: Muir JF, Roberts RJ (eds) Recent advances in aquaculture, Vol 3. Croom Helm, London, p 139-224

Bullock AM, Coutts RR (1985) The impact of solar ultraviolet radiation upon the skin of rainbow trout, Salmo gairdneri (Richardson), farmed at high altitude in Bolivia. J Fish Dis 8:263-272

Bullock AM, Roberts RJ (1979) Induction of UDN-like lesions in salmonid fish by exposure to ultraviolet light in the presence of phototoxic agents. J Fish Dis 2:439-441

Bullock AM, Roberts RJ (1981) Sunburn lesions in salmonid fry: a clinical and histological report. J Fish Dis 4:271-275

Bullock AM, Roberts RJ (1992) The influence of ultraviolet-B radiation on the mechanism of wound repair in the skin of the Atlantic salmon Salmo salar L. J Fish Dis 15:143-152

Bullock AM, Roberts RJ, Waddington P, Bookless WDA (1983) Sunburn lesions in koi carp. Vet Rec 112.551

Calkins J (1975) Measurements of the penetration of solar UV-B into various natural waters. In: Impacts of climatic change on the biosphere. CIAP Monograph 5, Pt 1, Ch 2 (Appendix E). Climate Impact Assessment Program, US Dept of Commerce, Washington, DC, p 267-298

Calkins J, Thordardottir $T$ (1980) The ecological significance of solar UV radiation on aquatic organisms. Nature 283 : $563-566$

DeLong DC, Halver JE, Yasutake WT (1958) A possible cause of 'sunburn' in fish. Prog Fish-Cult 20:111-113

Dunbar CE (1959) Sunburn in fingerling rainbow trout. Prog Fish-Cult 21:74

Ellis AE (1981) Inmunology of teleosts. In: Roberts RJ (ed) Fish pathology, 2nd edn. Baillière Tindall, London, p 103-117

Fabacher DL, Little EE (1995) Skin component may protect fishes from ultraviolet-B radiation. Environ Sci Pollut Res Int 2:30-32

Editorial responsibility: Carl Schreck

Corvallis, Oregon, USA
Frisch SM, Francis H (1994) Disruption of epithelial cellmatrix interactions induces apoptosis. J Cell Biol 124: $619-626$

Hayat MA (1986) Basic techniques for transmission electron microscopy. Academic Press, Orlando

Hunter JR, Kaupp SE, Taylor JH (1981) Effects of solar and artificial ultraviolet-B radiation on larval northern anchovy Engraulis mordax. Photochem Photobiol 34:477-486

Hunter JR, Taylor JH, Moser HG (1979) Effect of ultraviolet irradiation on eggs and larvae of the northern anchovy. Engraulis mordax, and the Pacific mackerel, Scomber japonicus, during the embryonic stage. Photochem Photobiol 29:325-338

Iger $Y$, Abraham $M(1990)$ The process of skin healing in experimentally wounded carp. J Fish Biol 36:421-437

Martinez JL, Fernandez B-de Quiros C, Baschwitz GG, Muñoz C (1987) Evolución de las lesiones causadas por Saprolegnia en el tequmento de trucha (Salmo trutta L.). Cuad Marisq Publ Téc 12:615-620

Matsumoto J, Seikai T (1992) Asymmetric pigmentation and pigment disorders in pleuronectiformes (flounders). Pigm Cell Res Suppi 2:275-282

Mittal AK, Munshi JSD (1974) On the regeneration and repair of superficial wounds in the skin of Rita rita (Ham.) (Bagridae, Pisces). Acta Anat 88:424-442

Peleteiro MC, Richards RH (1988) Immunocytochemical studies on immunoglobulin-containing cells in the epidermis of rainbow trout Salmo gairdneri Richardson: influence of bath vaccination. J Fish Biol 32:845-858

Peleteiro MC, Richards RH (1990) Phagocytic cells in the epidermis of rainbow trout, Salmo gairdnen Richardson. J Fish Dis 13:225-232

Phromsuthirak P (1977) Electron microscopy of wound healing in the skin of Gasterosteus aculeatus. J Fish Biol 11:193-206

Pickering AD, Richards RH (1980) Factors influencing the structure, function and biota of the salmonid epidermis. Proc R Soc Edinb 79B:93-104

Roberts RJ (1975) Melanin-containing cells of teleost fish and their relation to disease. In: Ribelin WE, Migaki $G$ (eds) The pathology of fishes. The University of Wisconsin Press, Madison, p 399-428

Roberts RJ, Bullock AM (1981) Recent observation on the pathological effects of ultraviolet light on fish skin. Fish Pathol 15:237-239

Robertson DA, Roberts RJ, Bullock AM (1981) Pathogenesis and autoradiographic studies of the epidermis of salmonids infested with Ichtyobodo necator (Henneguy, 1883). J Fish Dis 4:113-125

Sanders EJ, Wride MA (1995) Programmed cell death in development. Int Rev Cytol 163:105-173

Setlow RB, Woodhead AD, Grist E (1989) Animal model for ultraviolet radiation-induced melanoma: platyfishswordtail hybrid. Proc Natl Acad Sci USA 86:8922-8926

Smith RC, Baker KS (1979) Penetration of UV-B and biologically effective dose-rates in natural waters. Photochem Photobiol 29:311-323

Spurlock BO, Skinner M, Kattine A (1966) A simple rapid method for staining epoxy embedded specimens for light. microscopy with the polychromatic stain paragon-1301 Am J Clin Pathol 46:252-258

Wyllie AH, Kerr JFR, Currie AR (1980) Cell death: the significance of apoptosis. Int Rev Cytol 68:251-306

Submitted: October 23, 1996; Accepted: August 5, 1997

Proofs received from author(s): October 1, 1997 